\title{
ENSINO RELIGIOSO NAS ESCOLAS PÚBLICAS: A PROPÓSITO DE UM SEMINÁRIO INTERNACIONAL
}

\author{
Luiz ANTÔNio CunHA*
}

\begin{abstract}
RESUMO: O status do ensino religioso nas escolas públicas em cinco países é apresentado neste artigo, que é resultado da participação do autor em seminário da Association Francophone d'Education Comparée, em Sèvres (França), em outubro de 2005. Com base nos textos apresentados e na bibliografia dos conferencistas principais, a diversidade da situação internacional é apresentada e nela se verificam surpreendentes contrastes e semelhanças.
\end{abstract}

Palavras-chave: Ensino religioso. Laicização. Educação comparada. Política educacional.

\section{RELIGIOUS EDUCATION IN PUBLIC SCHOOLS: APROPOS OF AN INTERNATIONAL CONFERENCE}

ABSTRACT: This paper presents the situation of religious education in public schools in five countries. It derives from the author's participation in a conference promoted by the Association Francophone d'Education Comparée (Sèvres, France, October 2005). Drawing on the lectures delivered at the conference and on keynote speakers' bibliographies, it offers an overview of the international situation of the subject and discusses some unexpected similarities and contrasts.

Key words: Religious education. Laicization. Comparative education. Educational policy.

* Doutor em Educação e professor da Faculdade de Educação da Universidade Federal do Rio de Janeiro (UFRJ). Home page: www.luizantonio.cunha.nom.br 
ano de 2005 marcou o centenário da lei de separação entre Igreja e Estado, na França. Menos pela data do que pela relevância e atualidade do tema no contexto francês e mundial, a Association Francophone d'Éducation Comparée (AFEC) e o Centre Internationale d'Études Pédagogiques (CIEP) ${ }^{1}$ promoveram o seminário Éducation, Religion, Lä̈cité, em outubro de 2005, no qual foram apresentadas comunicaçóes e intervenções em mesas redondas que abordaram a questão em 25 países, ${ }^{2}$ além dos temas pertinentes a questôes gerais.

O Brasil foi objeto da comunicação intitulada "L'enseignement religieux aux écoles publiques Brésiliennes: formation des modeles hégémoniques", que escrevi junto com Ana Maria Cavaliere, colega da Faculdade de Educação da Universidade Federal do Rio de Janeiro (UFRJ). Mostramos que, em nosso país, o campo educacional tem, atualmente, um grau de autonomia menor do que o de duas décadas atrás, quando se preparava a Assembléia Nacional Constituinte. No que concerne ao ensino religioso nas escolas públicas, a derrota política dos setores laicos ativos é um componente, dentre outros, da regressão do campo educacional, no que concerne à sua autonomização diante do campo político e do campo religioso.

Embora seja geral a tendência de perda da autonomia do campo educacional, no Brasil de hoje, ela se mantém maior em São Paulo do que no Rio de Janeiro. Com efeito, neste estado ocorre um verdadeiro retrocesso no grau anteriormente alcançado, ou seja, os campos político, religioso e educacional tornam a se confundir, segundo padrões que lembram o Estado Novo. Em conseqüência, o Rio de Janeiro foi a primeira (e única até agora) unidade da Federação a instituir o concurso para professores do ensino de religião na rede pública, bem como a transferir para as entidades religiosas o poder de credenciar e descredenciar esses docentes - vale dizer, a lhes delegar o poder de destituir professores de seu quadro.

Mas, o objetivo deste artigo não é transcrever o texto referente ao Brasil, mas, sim, o de apresentar um panorama mundial que, sem a pretensão de ser exaustivo, ajude o leitor brasileiro a ter uma idéia da diversidade da situação de outros países.

Antes de tudo, vale informar que as comunicações apresentadas no seminário podem ser facilmente acessadas pela página da AFEC. As referências impressas compreendem a coletânea organizada por Jean- 
Paul Willaime ${ }^{3}$ e Séverine Mathieu (2005), assim como o dossiê sobre o tema "Escola e Religião", publicado no n. 36 da Revue Internationale d'Éducation, editada pelo CIEP, co-promotor do seminário em foco, publicaçóes essas que foram de grande valia para enriquecer as comunicações ao seminário.

Passo, então, a apresentar o status do ensino religioso nos cinco países que considerei mais interessantes para a composição do panorama, e para os quais eu dispunha de informaçóes suficientes para esse propósito: França, Alemanha, Itália, Grã-Bretanha e Estados Unidos.

\section{França}

Apesar das antigas posições, mais anticlericais do que anti-religiosas, dos iluministas e dos revolucionários de 1789, a laicidade escolar só vingou, na França, em 1882, antes mesmo da lei de separação entre Igreja e Estado, que é de 1905. Ao contrário do laicismo dos proclamadores da República brasileira, que se inspirou no francês, mas ao qual faltava o apoio popular, a história daquele país mostra que as guerras religiosas e os massacres de huguenotes pelos católicos forneceram uma forte base de apoio para toda a política que impedisse a religião dominante de usar o Estado como instrumento de poder religioso e, conseqüentemente, político. Mais recentemente, o apoio que a Igreja Católica deu ao regime de Vichy e, por via de conseqüência, à colaboração com os ocupantes alemães, justificada pela ideologia do anticomunismo, forneceu outra base para se evitar a repetição do uso do Estado por qualquer sociedade religiosa.

A lei de 1882 proibiu o ensino religioso nas escolas públicas, assim como a presença de símbolos religiosos nesses estabelecimentos. Ao contrário da imagem radical divulgada na bibliografia educacional, a implantação dessa lei foi gradual, seguindo a orientação do próprio ministro da educação, Jules Ferry, para que as autoridades escolares usassem de temperança. Da mesma maneira, procedeu-se em 1944. Como o regime de Vichy havia reintroduzido o crucifixo nas salas de aula das escolas públicas, o governo instituído pela Libération determinou que sua retirada seguisse o mesmo tom de temperança, para não chocar as famílias católicas, principalmente no interior do país. A lei de 1882 previa, também, que as escolas primárias não tivessem aula nas quin- 
tas-feiras (depois de 1972, nas quartas), de modo que os alunos pudessem ter ensino religioso nas paróquias, se quisessem. Na linha da implantação gradativa, muitas escolas públicas foram cedidas aos párocos para ensinarem nelas o catecismo, fora do horário escolar. $\mathrm{O}$ dia livre segue até hoje, mas há forte pressão dos pais para que as aulas de sábado sejam transferidas para esse dia livre, de modo que as famílias possam gozar do fim de semana. Como disse um autor, é difícil a sobrevivência do "catéchisme contre le week-end".

Durante décadas, o lugar do ensino religioso foi ocupado por uma disciplina cujo conteúdo era a moral laica, sancionada pelo Estado. Ao fim dos anos de 1960, a disciplina Moral foi substituída pelo ensino da Filosofia, que, ao contrário daquela, não tem como objetivo a formação de bons cidadãos, mas, sim, o de desempenhar um papel explicito de crítica intelectual.

Embora o Estado francês fosse impedido, pela lei de 1905, de subsidiar qualquer culto, mantiveram-se mecanismos indiretos de subsídio, até hoje, tanto às escolas confessionais quanto às entidades assistenciais religiosas. Os estabelecimentos de ensino católicos, "contratados" pelo governo, somam hoje 8.500, com dois milhôes de alunos, ou seja, $20 \%$ da população escolar francesa (exceto no grau superior). Essas escolas ministram o programa oficial e adicionam o ensino religioso, com possibilidade de dispensa. Em menor número, há escolas evangélicas e judaicas nas mesmas condições, mas nenhuma islâmica, embora não haja razão alguma na legislação que o impeça. Depreendi, dos debates no seminário, que isso se deve ao mais baixo nível de renda da população muçulmana na França, comparativamente à de outros credos, o que a impediria de cobrir as diferenças entre o subsídio governamental às escolas "contratadas" e as mensalidades cobradas. Não foi possível saber se, além desse elemento econômico, existe alguma má vontade governamental.

Fora das aulas de ensino religioso, as escolas "contratadas" devem dar o mesmo tratamento na análise literária aos textos fundadores das grandes religiōes (a Bíblia e o Corão, principalmente), de modo a não constranger os alunos que não optaram pelo conteúdo confessional. Esses textos são também utilizados no collège $e^{4}$ público, embora predomine, aí, da parte de muitos professores, uma atitude de dessacralização, o que constrange os alunos das respectivas religiōes. 
Esse quadro político, único na Europa, está posto em causa desde o início dos anos de 1980, principalmente, e se intensifica, pelo que é chamado na França de "presença do comunitarismo na escola pública". Essa expressão designa os comportamentos, da parte dos pais de alunos e deles próprios, no sentido de se contraporem às práticas escolares correntes, em função de suas "comunidades religiosas", particularmente dos muçulmanos, mas dos quais não estão excluídos os judeus. Como aqueles são mais numerosos, vou comentar apenas o que lhes concerne.

Para certos analistas, a maré montante do "comunitarismo escolar” é resultado da potencialização de sentimentos espontâneos, realizada por militantes que pretendem tomar o poder nas organizações religiosas e de ajuda mútua muçulmanas, que, para isso, atiçam os jovens contra as práticas dos infiéis. Nas escolas públicas situadas em bairros com grande número de imigrantes de países de população muçulmana, as dificuldades apontadas são inúmeras e de difícil solução prática. Transcrevo certos exemplos que colhi na imprensa quotidiana francesa. 1) Numa escola primária, um pai não queria deixar sua filha aos cuidados do professor, exigindo profissional do sexo feminino. 2) A dificuldade de identificação das mães, que usam o véu islâmico que cobre o pescoço e todos os cabelos, obrigou a diretora de uma escola a reservar uma sala onde as mães despem o véu (não poderiam fazê-lo em público), de modo que, identificadas, recebam seus filhos. 3) Alunos muçulmanos de certa escola exigem vestiário separado para eles, pois os crentes circuncidados não podem ser vistos nus por infiéis. 4) Nas aulas de educação física, alunas muçulmanas recusam professor e exigem professora; negam-se a vestir roupa de banho e usar a piscina se houver homens à vista. 5) Alunas vestem seus mantôs quando são chamadas ao quadro, para evitar a "concupiscência" da parte de seus colegas. 6) $\mathrm{Na}$ cantina, recusa-se comer carne de animal abatido fora das prescrições religiosas. 7) Recusa da leitura da Bíblia, como texto literário, ou a exigência de professor crente para a leitura apropriada do Corão. 8) Exigência de local de culto para os muçulmanos. 9) Ausência das aulas nas sextas-feiras, inclusive por ocasião das provas. ${ }^{5}$

O proselitismo religioso tem aumentado muito nas escolas públicas, não só mediante a presença de alunos crentes, mas, principalmente, pela pressão destes sobre os provenientes de países de maioria muçulmana, para que cumpram certos preceitos, com destaque para o jejum do Ramadã. 
Diante de todos esses problemas, as atitudes variam muito. Alguns diretores praticam a negociação, outros a oposição pura e simples a essas práticas. Mas, na maioria dos diretores e professores, persiste um forte mal-estar diante do que entendem ser ou deva ser a escola republicana, igual para todos, sem adotar nem rejeitar a crença pessoal de ninguém.

A única medida de caráter geral tomada pelo governo foi quanto ao porte de símbolos religiosos nas escolas públicas. Depois de ampla discussão nacional, no parlamento, nos partidos políticos, na imprensa, nas organizações de todos os tipos, foi aprovada uma lei, em 15/3/ 2004, que interditou o porte de símbolos ou roupas que manifestem uma pertinência religiosa nas escolas públicas, desde que tenham "dimensão manifestamente excessiva”. A lei foi aprovada com expressiva maioria parlamentar, que foi maior ainda na regulamentação pelo Conselho Superior de Educação. Aliás, uma pesquisa realizada com os professores, em 2004 , revelou que $72 \%$ aprovavam a lei.

Cumpre esclarecer que a lei não proíbe qualquer símbolo religioso, mas apenas os mais ostensivos. Nada contra uma pequena cruz ou estrela de David ao pescoço, nem contra um véu na cabeça. A interdição vai contra uma batina católica, um quipá ou um véu que cobre o pescoço e todo o cabelo da cabeça das mulheres, até a raiz, só deixando a face de fora. Com mais razão, ainda, uma burka. Não consegui saber que procedimento os professores teriam diante de um aluno com turbante sikh. ${ }^{6}$

Cumpre esclarecer, também, que essa interdição se aplica até o liceu, ${ }^{7}$ não incidindo sobre o nível superior. Penso que a razão da exclusão da universidade é a grande presença de estudantes de origem estrangeira, tradição francesa desde a Idade Média, que se pretende manter e até ampliar, nos quadros do Protocolo de Bolonha, de reforma do ensino superior. Isso não quer dizer que o "comunitarismo" não exista na universidade pública. Se a vestimenta ou os símbolos religiosos não constituem problema, nem as roupas, os estudantes muçulmanos radicais têm repetido as exigências dos seus colegas mais novos na educação física e na recusa de certos textos e autores.

De todo modo, o problema se manifesta, sobretudo, nas escolas públicas primárias e secundárias, localizadas nos bairros de maior concentração de imigrantes do norte da África. Sua generalização é hoje 
mais temida do que verificada na prática. Assim, a divulgação televisiva, em 2004, mostrou algumas jovens impedidas de entrar em estabelecimentos públicos de ensino por usarem o véu islâmico. Mas não divulgou a entrada em outros estabelecimentos de muitas outras, nas mesmas condições, sem constrangimento. Foi possível registrar, no seminário, que, na maior parte das escolas, o diálogo e a espera resolveram os problemas desse tipo. Também não foi divulgado o fato de que a proibição do uso de tais símbolos religiosos ostensivos é apenas até o liceu, sendo livre no ensino superior. Mesmo nos do IUFM, ${ }^{8}$ o uso de símbolos mais ostensivos, como o véu islâmico, é livre no $1^{\circ}$ ano, mas interditado a partir do $2^{\circ}$, quando os alunos passam à condição de estagiários do sistema público de ensino. Um diretor de escola pública de Marselha, justamente a cidade da França com maior proporção de imigrantes de origem muçulmana, disse, em seu depoimento, que as meninas começam as aulas com o véu e, após algumas semanas, o tiram ao entrarem no estabelecimento.

Esses exemplos não eliminam o problema. Ele existe e, para a maioria dos professores e do público em geral, ele tende a crescer. Assim, não é descabido pensar que a "questão do véu islâmico", como fato mais político e mediático, pode ser uma construção artificial para, de um lado, as autoridades escolares submeterem moralmente estudantes imigrantes ou filhos destes, e, de outro, os alunos rejeitarem uma escola estranha e inamistosa, ainda que sua prática religiosa seja ocasional ou meramente ritual. Em suma, tudo em desacordo com a temperança recomendada por Jules Ferry.

Do que me foi possível ouvir e ler a respeito do tema em foco, a maior novidade foi o fato de as escolas públicas da Alsácia e da Lorena? oferecerem atualmente ensino religioso, como faziam quando eram parte da Alemanha. Nessa região, onde há cultos reconhecidos pelo Estado, a manifestação pública da religião de cada indivíduo é uma prática social antiga, que se expressa também no ensino religioso. Os credos reconhecidos, para os quais há aulas de ensino religioso, são o católico, o luterano, os "outros protestantes" e o judaico. No ensino primário e nos secundário os alunos têm uma hora por semana de ensino religioso de seu credo. No secundário, os professores desse ensino são ministros dos cultos, mas, freqüentemente, pessoal leigo, todos remunerados pelo Estado. São as autoridades religiosas que propõem sua nomeação. Os alunos podem ser dispensados dessas aulas, mas não há nada posto em 
Ensino religioso nas escolas públicas: a propósito de um seminário internacional

seu lugar, de modo que eles deixam as escolas no horário do ensino religioso.

Registrei, também, que as demandas dos dirigentes religiosos muçulmanos na França, no que diz respeito à incorporação de preceitos de seu credo no currículo escolar público, são incomparavelmente menores e menos agressivas do que as demandas da Igreja Católica durante décadas. Hoje as demandas católicas e cristãs, de um modo geral, ${ }^{10}$ são pequenas, ajustadas que estão à laicidade em vigor e ao regime de escolas "contratadas". Assim, há quem pense que o ajustamento muçulmano ao status quo seja questão de tempo e de política bem conduzida. Manifestei minhas reservas quanto a esse otimismo por causa da interveniência de fatores inexistentes anteriormente, como o de nacionalidade, etnia, mercado de trabalho e, principalmente, a utilização das populações muçulmanas como base de recrutamento, esconderijo e fonte de financiamento de organizações terroristas. Tudo isso é muito diferente das ingênuas acusações que se faziam, no passado, ao clero católico como agentes de uma entidade estrangeira, o Vaticano.

Um dos momentos de mais acalorados debates foi por ocasião da mesa redonda "Les rapports religion, éducation, laïcité: quels enjeux, hier et aujourd'hui, pour les politiques éducatives dans le monde?", quando se tratou do ensino do "fato religioso" na escola pública francesa, na linha da proposta de Régis Debray, defendida pelo conferencista Jean-Paul Willaime.

O fato religioso é um objeto do conhecimento científico, portanto um fenômeno objetivamente observável, mediante o emprego do método científico. As religióes são, assim, apreendidas como fatos sociais, políticos, culturais, mentais e civilizatórios - históricos, o que quer dizer que são produto da vida humana em sociedade. No currículo escolar francês, é na disciplina História que o fato religioso é tratado.

Diante da defesa de Willaime de uma maior abertura para o fato religioso na escola pública, além de seu tratamento pela História, houve intensa reação, no seminário em foco, da parte de alguns participantes muçulmanos sub-saarianos, para quem a religião não deveria ser objeto de conhecimento, mas, sim, de vivência, no que foram contraditados pelos partidários do ensino laico nas escolas públicas, franceses e não franceses. 


\section{Alemanha}

O armistício entre católicos e protestantes, ao fim das guerras de religião do século XVII, fundamenta, até hoje, o ensino religioso nas escolas públicas alemãs, com o acréscimo do disposto pela Constituição federal de 1949. Esta determina que o ensino religioso seja obrigatório nas escolas públicas, prevendo a dispensa, caso em que atividades alternativas devem ser oferecidas aos alunos.

A regulamentação do dispositivo constitucional sobre questôes educacionais é feita pelos estados federados, o que propicia situações distintas entre eles. Por exemplo, na Baviera, entre os objetivos gerais da educação está o "respeito a Deus"; em Bade-Wurtemberg, a educação deve ser ministrada "na consciência de Deus e no amor cristão ao próximo"; em Hesse, a missão educativa da escola repousa sobre "a tradição humanista e cristã”. Nas escolas públicas, há cerimônias religiosas para celebrar o início e o fim do ano letivo, das quais os alunos e professores devem participar.

Os programas do ensino religioso nas escolas públicas são elaborados pelas sociedades religiosas - protestante, católica e judaica. Mais raramente, a Igreja Ortodoxa é chamada a elaborar o seu, nas áreas de maior contingente imigrante grego. A pequena institucionalização do clero muçulmano, quando comparado com o daquelas, dificulta, para as autoridades educacionais estatais, a inclusão de mais uma religião no elenco da oferta. Isso, a despeito do número de imigrantes muçulmanos ser crescente, na Alemanha, o que faz com que as escolas públicas tenham 800 mil alunos desse credo.

$\mathrm{Na}$ linha de uma progressiva secularização do país, alguns estados instituíram atividades opcionais ao ensino religioso nas escolas públicas, nas quais as questões religiosas são abordadas, mas com distanciamento, predominando o caráter informativo. Há cursos de Ética (Bade-Wurtemberg, Hesse, Renânia-Palatinato, Saxe, SaxeAnhalt), de Valores e Normas (Baixa Saxônia); de Filosofia Prática (Bremem, Schleswig-Holstein, Mecklembourg-Pomerânia, RenâniaWestfália).

Os debates em torno da questão do ensino religioso nas escolas públicas são intensos e parecem estar longe de um consenso. Vejamos alguns exemplos que consegui reter. 
A Igreja Luterana defende um ensino religioso ecumênico, enquanto a Igreja Católica prefere seu oferecimento separado pelas diversas confissões, como é feito atualmente.

$\mathrm{Na}$ Baviera, onde a lei manda colocar o crucifixo na sala de aula, em lugar proeminente, um grupo de pais de alunos impetrou ação na justiça exigindo a retirada desse símbolo religioso, em atendimento ao dispositivo constitucional da liberdade de culto. A Corte Constitucional decidiu a favor dos pais, contra a lei bávara, que seria, neste aspecto, inconstitucional. Em reação, o parlamento do estado elaborou outra lei, mandando repor o crucifixo no mesmo lugar, mas adicionou uma cláusula que previa sua retirada no caso da solicitação dos pais, em determinadas condições, driblando, assim, a Constituição, naquilo que ela dizia não haver religião oficial.

No estado de Brademburgo, a decisão de 1996 de substituir o ensino religioso nas escolas públicas pela "Concepção da vida ético-religiosa” foi combatida pelas igrejas Luterana e Católica, de modo que aquele foi restabelecido como matéria obrigatória, mantida esta como optativa.

O uso de véus islâmicos pelos alunos não encontra problema, mas ele é vedado aos professores que seguem esse credo. Uma candidata ao magistério, que portava esse véu, teve sua inscrição recusada em processo seletivo, apesar do protesto das associações muçulmanas, que denunciaram a discriminação: a ostentação dos símbolos cristãos nas escolas e a recusa do muçulmano.

\section{Itália}

O ensino religioso nas escolas públicas, particularmente do catolicismo, existe desde antes da criação do Estado italiano unificado, na segunda metade do século XIX, edificado contra os Estados Pontifícios, que foram incorporados. A Igreja Católica foi separada do Estado, mas o ensino religioso católico nas escolas públicas jamais foi seriamente ameaçado pelo poder político - muito pelo contrário. Foi por isso que Bertrand Remi disse que a Igreja foi separada do Estado, mas não da escola pública.

A Concordata entre o Estado fascista e o Vaticano, em 1929, dizia que "o ensino da religião cristã, segundo a forma recebida da tradi- 
ção católica, fundamenta e coroa a instrução pública”. Em conseqüência, o ensino religioso, até então restrito ao ensino primário, foi estendido ao secundário. A dispensa, admitida formalmente, era examinada caso a caso. Admitia-se a possibilidade de cessão de espaço na escola para o ensino religioso não católico, fora do horário das aulas, quando o número (indeterminado) de alunos justificasse esse procedimento, o que, na prática, o impossibilitava.

Derrotado o fascismo, a Constituição de 1948 assegurou a liberdade de crença religiosa, mantendo-se a separação entre a Igreja Católica e o Estado, assim como a Concordata, com os votos inclusive do Partido Comunista - indiscutível hegemonia! Em conseqüência, o ensino específico da religião católica foi mantido nas escolas públicas, gerido conjuntamente pela Igreja e pelo Estado. Todavia, o ensino religioso nas escolas públicas está baseado na Concordata, não na Constituição.

Em 1984, nova Concordata entre o Estado italiano e o Vaticano estabelecia que "os princípios do catolicismo fazem parte do patrimônio histórico do povo italiano", mas dizia que, em função da liberdade de consciência e da responsabilidade educacional dos pais, garantia-se a cada um o direito de escolher seguir ou não o ensino religioso católico nas escolas públicas. Para evitar interpretações que pudessem pôr em perigo a hegemonia do catolicismo, um acordo realizado no ano seguinte determinou que as classes de ensino religioso católico seriam oferecidas independentemente da demanda dos alunos ou de seus pais: duas horas por semana nas escolas maternais e primárias, uma hora por semana nos colégios e liceus. Ademais, todos os docentes de ensino religioso deveriam ser formados em instituições aprovadas pela Santa Sé e ter o nihil obstat do bispo da diocese onde cada escola se localiza. Uma lei de 2003 integrou os professores do ensino religioso (católico) nos quadros do funcionalismo do Estado.

Os alunos dispensados do ensino religioso deveriam seguir "horas alternativas” de estudo dirigido e de educação cívica, que, em geral, eram mal organizadas, o que não estimulava os alunos a optarem por essa possibilidade. Decisão da Corte Constitucional, em 1991, autorizou os alunos dispensados do ensino religioso a deixarem a escola naquele horário. Mesmo assim, em Milão, no ano letivo 2003/2004, apenas $7 \%$ dos alunos das escolas maternais e primárias não seguiram o ensino religioso, proporção essa que subiu a 33\% para os alunos dos liceus propedêuticos e a $50 \%$ para os dos liceus técnicos. Para o con- 
Ensino religioso nas escolas públicas: a propósito de um seminário internacional

junto do país, a proporção de alunos do liceu dispensados das aulas de religião aumentou de 12\%, em 2001, para 38\%, em 2005.

A ostentação de símbolos religiosos católicos nas escolas públicas tem sido objeto de disputas. A presença do crucifixo nas salas de aula não é generalizada, nem os professores se sentem obrigados a entronizálo. Contudo, tal presença é mais comum do que a ausência. Em atendimento à demanda de um cidadão italiano convertido ao islamismo, o tribunal de Áquila determinou que fosse retirado o crucifixo das salas de aula freqüentadas por suas filhas (escola maternal e primária). Essa decisão não foi implementada, pois, em segunda instância, argüiu-se a incompetência do Poder Judiciário de decidir sobre essa matéria, que seria da alçada exclusiva da administração escolar. A despeito dos apelos públicos do papa João Paulo II, uma sessão da Corte Constitucional, em 2000, decidiu que o crucifixo, enquanto símbolo isolado, não faz parte, intrinsecamente, da herança cultural italiana. Nova fonte de conflito foi recentemente aberta por uma mãe finlandesa, sem relação alguma com o Islã, que reivindicou a retirada desse símbolo católico das salas de aula da escola pública freqüentada por seus filhos. Recentemente, uma professora de escola primária, que usava o véu islâmico, moveu ação em sua defesa e foi amparada pelo Estado.

Em dezembro de 2004, mais uma questão surgiu, desta vez relativa aos presépios natalinos nas escolas públicas. Em respeito às crenças de alunos não católicos, algumas escolas decidiram retirá-los, o que provocou apelo público da Confederação Episcopal Italiana para que os presépios fossem mantidos. Para Remi, revelou-se, aí, mais uma confusão de poderes: a Igreja Católica persiste em situar-se no campo político, recusando-se a se retirar para a esfera privada, permanecendo, como no diagnóstico de Antonio Gramsci, "uma sociedade civil na sociedade civil”.

Naquele ano, $82 \%$ da população concordavam com a presença do crucifixo nas salas de aula das escolas públicas, enquanto que $76 \%$ rejeitavam o uso do véu muçulmano nas escolas públicas.

A despeito desses números, Pace diz que enquanto há uma crescente laicidade nos costumes da população italiana, enquanto existem professores que procuram oferecer um espaço laico e livre para o encontro de tradições religiosas diferentes, paradoxalmente, os dirigentes políticos e a opinião pública atribuíram à Igreja Católica o papel de 
mestre da moral pública, transformando, assim, o ensino de religião nas escolas estatais numa espécie de educação dos valores cristãos, fundadores da identidade nacional. Esse paradoxo é responsável pelo acúmulo de tensões culturais e políticas no sistema público de educação.

Aliás, a crença de que os italianos são todos católicos foi construída durante o período de hegemonia do Partido Democrata Cristão (1949/1972). Desde este último ano, parcelas crescentes de fiéis católicos têm se manifestado em questões políticas contrariamente às recomendações das autoridades eclesiásticas, definindo uma rota na direção da laicização da sociedade italiana.

\section{Grã-Bretanha}

Nesse país, o rei ou a rainha é o dirigente máximo da Igreja Anglicana, desde o século XVI, um fato único de ligação entre religião e poder político na Europa. O primeiro corolário dessa ligação é a existência de cultos coletivos nas escolas públicas, os quais devem ser todo ou principalmente de caráter cristão (não necessariamente anglicano).

O ensino religioso é obrigatório nas escolas públicas, prevendo-se a possibilidade de dispensa, sem que esteja prevista alguma atividade alternativa para os alunos que a requeiram. A lei da reforma educacional de 1988 diz que o programa de educação religiosa deve refletir o fato de que, na Grã-Bretanha, as tradições religiosas são essencialmente cristãs, mas que se deve levar em conta outras religióes praticadas no país.

Em 1944 foram elaborados dois programas típicos, envolvendo seis tradições religiosas: cristã, judaica, islâmica, induísta, budista e sikh. Contudo, esses programas servem apenas de referência para os conselhos locais, que podem ignorá-los. De fato, os programas das community schools (totalmente mantidas pelo Estado) são elaborados por um conselho local, com representantes de quatro grupos: (a) Igreja Anglicana; (b) outras confissões religiosas; (c) representantes dos professores; e (d) representantes dos conselheiros municipais. A juízo do conselho local, outros membros podem ser chamados, como representantes dos grupos humanistas, por exemplo.

Foi uma surpresa encontrar convergência de manifestações tendentes a mostrar um panorama harmônico "multicultural" na escola pública britânica. Dizia-se que, a despeito de pendências pontuais, os 
alunos poderiam usar símbolos religiosos nas escolas públicas; ademais, elas oferecem cardápios variados nas cantinas, conforme as prescrições dos grupos religiosos mais freqüentes. Todavia, os conflitos entre católicos e protestantes na Irlanda do Norte não foram objeto de nenhuma comunicação nem dos textos consultados.

Apesar da imagem pacífica que a ideologia do multiculturalismo divulga, há conflitos entre jovens dos bairros de população de origem européia e de origem asiática, de religião muçulmana, que atingiram o clímax em 2001. Aliás, conflitos entre imigrantes de origem indiana e paquistanesa não estão fora de cogitação, por causa dos conflitos religiosos desde antes da independência de ambos os países. ${ }^{11}$

Notícia publicada na imprensa inglesa, transcrita na brasileira, em novembro de 2005, dizia que o Imperial College, que integra a Universidade de Londres, proibiu o uso de capuzes, gorros e véus islâmicos, por estudantes e funcionários. A razão apresentada foi a segurança do estabelecimento: a identificação das pessoas que circulam no campus torna-se difícil quando parte da cabeça está encoberta. A matéria não fez referência ao uso de turbantes sikhs, mas mencionou o protesto dos estudantes muçulmanos da instituição contra o que entendiam ser uma discriminação inaceitável.

\section{Estados Unidos}

George M. Thomas intitulou seu capítulo, na coletânea de Willaime e Mathieu, de "Estados Unidos: a mais religiosa e a mais secularizada das naçôes". Com essa expressão, ele bem sintetizou sua tese: se, de um lado, a religião é um fenômeno importante na sociedade norte-americana, a Constituição do país determina, indireta, mas fortemente, que as escolas públicas sejam religiosamente neutras.

A primeira emenda à Constituição determina que "O Congresso não deve promulgar lei que favoreça a institucionalização de uma religião ou que interdite seu exercício”. Em conseqüência, a prece pública está interditada na escola, assim como a leitura da Bíblia nas cerimônias escolares, pois, mesmo no âmbito cristão, é sabido da diversidade da interpretação de seu texto. $\mathrm{O}$ ensino confessional não pode ser ministrado na escola, por pessoal interno nem externo.

A despeito dessa interdição, a manifestação religiosa dos alunos não sofre qualquer restrição, mesmo no âmbito da escola pública. Eles po- 
dem portar símbolos e vestimentas religiosas, levar sua própria refeição, preparada conforme prescrições religiosas. Os alunos podem mesmo tentar convencer seus colegas, desde que não cheguem ao proselitismo. Podem distribuir literatura. Eles podem se reunir no ambiente da escola com propósitos religiosos, mas esses eventos não podem contar com pessoal externo, como padres, ministros, rabinos e similares.

Contrariamente à liberdade dos alunos, os docentes têm uma margem muito limitada para expressar seu credo religioso. Eles devem privar-se de comunicar suas crenças pessoais aos alunos, assim como não podem divulgá-las, nem mesmo nas horas de recreio ou após o término das aulas. A fixação de material de caráter religioso nos quadros é controlada e deve submeter-se à regra da neutralidade religiosa.

A única maneira pela qual a religião pode integrar os programas escolares públicos é sob a forma de história da religião, de estudo literário da Bíblia ou de estudo sociológico da religião como fenômeno cultural.

Não há regra federal em matéria de vestimenta, de modo que isso fica a cargo dos estados. Há os que autorizam os professores a usarem roupas de caráter religioso, como o turbante sikh ou a batina católica, enquanto outros as interditam explicitamente. As decisões da Corte Federal são, nesses casos, raras e contraditórias. Com apoio em decisão judicial, uma escola impediu professora de lecionar usando o véu islâmico; já outra escola obteve decisão judicial que favoreceu professora em situação idêntica. Como o direito, na tradição anglo-saxônica, é baseado fortemente na jurisprudência, é provável que essas decisões contraditórias suscitem a manifestação da Suprema Corte.

A reorientação para a direita da política norte-americana, desde os anos de 1980, favoreceu a demanda de grupos conservadores de promulgação de leis que introduzam o ensino religioso nas escolas públicas, mas sem sucesso. No entanto, o favorecimento das escolas religiosas se fez mediante os subsídios financeiros diretos ou via vales escolares (vouchers), de modo que mais e mais pais ponham os filhos em escolas privadas confessionais.

O impedimento legal para a introdução do ensino religioso nas escolas públicas norte-americanas me leva a pensar que a pressão para a introdução do "design inteligente", como se fosse uma hipótese alternativa à teoria da evolução de Darwin, nas aulas de Biologia, seja uma tentativa de contornar essa barreira. 


\section{Considerações finais}

Há muito mais a digerir nas comunicaçoes apresentadas no seminário e nas discussóes que elas suscitaram, do que o panorama aqui esboçado. A leitura dos textos referidos, tanto os do dossiê da Revue Internationale d'Éducation quanto os da coletânea de Willaime e Mathieu, abrirá novos horizontes para a reflexão sobre a questão do ensino religioso nas escolas públicas. Material bibliográfico adicional, não referido aqui, ampliará ainda mais esses horizontes. Ainda que provisoriamente, apresento abaixo seis pontos, à guisa de observaçôes gerais, assim como de conclusōes a que cheguei ou que foram reforçadas em meu pensamento.

1 - Antes de ser uma questão propriamente religiosa ou mesmo pedagógica, a presença da religião na escola pública é uma questão política, com antigas e profundas raízes históricas. Essa conclusão foi reforçada pela discussão a respeito dos 25 países objeto das comunicações apresentadas no seminário. A Reforma Protestante, no século XVI, seguida da Contra-Reforma Católica, e as guerras de religião travadas na Europa, nesse século e no seguinte, forneceram uma base para as políticas estatais a respeito da religião na escola pública. Dentre os países considerados neste texto, a Itália e os Estados Unidos ocupam pólos opostos. A Itália pouco sofreu com aquelas guerras, devido à hegemonia desfrutada pelo papado, de modo que persiste, nesse país, a tutela religiosa católica sobre a sociedade civil, embora cada vez mais contestada. O efeito dessa mudança, no campo educacional, é a provável queda futura da posição dominante do ensino da religião católica nas escolas púbicas, mais por força da secularização das relaçôes sociais do que pela competição interna ao campo religioso. Os Estados Unidos, por sua vez, guardaram a herança dos primeiros colonizadores, que deixaram a Europa por causa de perseguiçōes religiosas, de modo que instituíram as escolas públicas laicas, embora a sociedade seja profundamente marcada pela presença do sagrado e do transcendente. Numa outra dimensão, a França e a Alemanha ocupam pólos opostos. Na França a religiáo é excluída da escola, a não ser como objeto de estudo científico, especialmente pela História. Na Alemanha, ainda marcada pela Paz de Westfália, há cultos reconhecidos pelo Estado que encontram guarida nas escolas públicas, inclusive com 
presença no currículo. Mas, em certas unidades da federação alemã, o lugar da religião nas escolas públicas está sendo ocupado pela filosofia e pela moral laica. Os sinais religiosos islâmicos, principalmente os véus femininos, encontram oposição variada em países situados em diferentes posições. Embora as justificativas variem, está clara a resistência ideológica diante da crescente presença política de contingentes imigrantes (e/ou de seus descendentes nacionais), de origem islâmica, que podem desempenhar novos e temidos papéis no campo político dos distintos países, assim como na política internacional. O grande número relativo desse contingente na França ( $10 \%$ da população), em sua maioria proveniente das ex-colônias, mais as práticas urbanísticas de segregação urbana e suburbana fazem com que esse país apresente os conflitos mais intensos de toda a Europa.

2 - A religião é uma questão de mercado internacional. Se, para os brasileiros, é fato corriqueiro a importação de sacerdotes católicos (ainda hoje e principalmente da Europa) e de missionários evangélicos (principalmente dos EUA, mais no passado do que no presente), é pouco conhecida a exportação de missionários evangélicos brasileiros para outros países latino-americanos, para os africanos, para os Estados Unidos e até para a Europa. Uma via de mão dupla se abriu, pois, no fluxo internacional de agentes religiosos, com o conseqüente fluxo de recursos financeiros. Depois do fim do socialismo no Leste Europeu, essa região como que constituiu um mercado de amplas possibilidades, aberto à competição religiosa, para onde se deslocam levas de missionários evangélicos norte-americanos. A voracidade com que o papa João Paulo II atuou no processo de independência unilateral da Eslovênia e da Croácia, províncias da antiga Iugoslávia, de herança católica romana, foi decisiva no modo pelo qual se deu a fragmentação daquele país, cujas terríveis conseqüências têm sido debitadas aos cristãos ortodoxos sérvios. O Oriente Médio, por sua vez, transformou-se numa região exportadora de agentes islâmicos para outras regióes do Oriente e até para a Europa. Os países de grande contingente populacional islâmico da África Sub-Sahariana têm importado do Magreb professores para suas escolas corânicas. O domínio da língua árabe, tanto quanto a devoção, parece ter recomendado a escolha dessa fonte de supri- 
mento docente-missionária. Esse fluxo de agentes religiosos, particularmente os islâmicos, transformou-se em questão de segurança nacional para certos países europeus, que o associam ao trânsito internacional de terroristas. A França manteve, nessa questão, uma posição radical, que é a exigência da formação interna dos imãs, rejeitando sua importação de outros países, mesmo os das suas antigas colônias magrebinas.

3 - Em conversa durante o intervalo entre as sessões, apresentei a um grupo heterogêneo de participantes do seminário como eu entendia um dos principais vetores de mudança do campo religioso no Brasil, nas últimas duas ou três décadas. Mostrei a importância das migraçôes campo-cidade e inter-regional, que jogam um grande contingente populacional em situação de miséria material, mas, principalmente, em situação de perda das relações de solidariedade social, sem que outras sejam postas em seu lugar. A conversão do catolicismo e da umbanda para as religiões evangélicas pentecostais, que prescrevem códigos rígidos de conduta, surge, para essa população, como a alternativa viável de reconstrução de novas identidades culturais no espaço social de destino. Com surpresa, ouvi de um magrebino que coisa parecida acontecia nas ex-colônias francesas do norte da África; e, de um francês, que o mesmo ocorria em seu país, com os imigrantes provenientes dessa região.

4 - A França, pátria da democracia política, permanece como uma ilha de ensino público laico na Europa confessionalista. Em nome da democracia, o ensino religioso foi retirado das escolas públicas, assim como o uso de símbolos religiosos ostensivos nos estabelecimentos de ensino primário e secundário. Os professores não só estão interditados de exibirem símbolos religiosos como, também, de manifestarem suas crenças diante dos alunos. As duas maiores democracias do mundo, os Estados Unidos e a Índia, estão mais próximas da França, nessa matéria, do que de outros países europeus, particularmente de sua antiga metrópole, a Grã-Bretanha. Naqueles dois países, o ensino é totalmente laico nas escolas públicas e os professores estão interditados de manifestarem suas opções religiosas diante dos alunos, embora não haja restrição para manifestações discentes dentro das escolas. O uso de símbolos religiosos é igualmente livre. Mas, tam- 
bém nos Estados Unidos, foi assinalada restrição ao uso de vestuário islâmico por professor de escola pública. Não é descabida a suposição de que, depois do 11 de setembro de 2001, tais restriçôes tenham se acentuado. É interessante ter em conta que, se os Estados Unidos foram considerados, por um dos autores comentados neste texto, como "a mais religiosa das naçôes", isso não foi obstáculo para a laicidade do ensino público - justamente o contrário. $\mathrm{O}$ mesmo acontece na Índia, país onde a ampla e forte presença na religião na sociedade civil é sobejamente conhecida. Na Grã-Bretanha, a situação é bem outra. O país faz alarde do "multiculturalismo", de sua tolerância para com os diferentes, embora a prática o desminta. Notícias recentes dão conta de que medidas de controle do segmento islâmico da população, por questôes de segurança, levaram à adoção de práticas restritivas similares às de outros países. A execução de um imigrante brasileiro, em 2005, pela polícia britânica em Londres, por suspeição de terrorismo, foi um golpe na propaganda desse país, que se jacta de possuir uma polícia mais preventiva do que repressora. Aliás, a Irlanda do Norte já havia dissolvido a imagem mediática da polícia e do exército britânicos.

5 - Parece claro que as religiões monoteístas originadas no Oriente Médio (judaísmo, cristianismo e islamismo) pretendem utilizar as escolas públicas para a difusão de suas idéias, seus valores e suas práticas. O grau com que expressam essa demanda varia com a força política que as entidades religiosas dispõem em cada país, bem como do grau com que seus seguidores efetivos ou potenciais utilizam os sistemas públicos de ensino. A comparação com as duas outras grandes religiões mundiais, o budismo e o hinduísmo, evidencia o desinteresse destas pela instrumentalização das escolas públicas para a difusão dos respectivos credos.

6 - Tudo somado, há quem veja uma tendência lenta, mas persistente de secularização das relações sociais na Europa, que poderá resultar no enfraquecimento da presença do ensino religioso nas escolas públicas, embora a presença da religião, como tema de estudo, conviva com a moral laica. Se efetivada, essa tendência distanciará a Europa do Brasil, pois, em nosso país, a tendência é justamente a oposta, ou seja, a confusão entre a religião e a política, no âmbito do Estado, instrumentalizada a escola 


\section{pública como espaço de disputas do mercado religioso. Lamenta- velmente, a derrota dos grupos laicos, nas lutas pela Constituição de 1988 e da LDB de 1966, facilitou a regressão no processo de autonomização do campo educacional brasileiro.}

\section{Recebido em fevereiro de 2006 e aprovado em março de 2006.}

\section{Notas}

1. O CIEP é a entidade do Ministério da Educação encarregada da difusão da língua francesa no estrangeiro e da cooperação internacional. Sua sede fica em Sèvres, na região metropolitana de Paris, onde foi realizado o seminário.

2. Foram 12 países europeus, 5 africanos e 8 de outras regiōes.

3. Jean-Paul Willaime é diretor do Institut Européen en Sciences des Religions, criado pelo Ministério da Educação da França, em 2002, em decorrência das sugestōes de Régis Debray no relatório "L'enseignement du fait religieux dans l'école laïque". O IESR integra a École Pratique des Hautes Etudes, uma das mais respeitadas instituições de pesquisa e ensino daquele país. No seminário em foco, Willaime participou da sessão plenária "Les rapports religion, éducation, laïcité: quels enjeux, hier et aujourd'hui, pour les politiques éducatives dans le monde?".

4. Mais ou menos equivalente ao ensino fundamental brasileiro, da $5^{\mathrm{a}}$ à $8^{\mathrm{a}}$ Série.

5. Nesse ponto, os muçulmanos são replicados pelos judeus e adventistas, quanto aos sábados.

6. A dificuldade de se ter uma posição desprovida de ambigüidades diante do que seriam os símbolos religiosos, "de dimensão manifestamente excessiva", está presente na capa do livro de Willaime e Mathieu, já referido. Numa charge bem humorada, uma jovem vestida até os pés e com os cabelos todos envoltos por um véu dirige-se a um rapaz vestido com roupas que trazem as grifes ostensivas: Nike e Reebok, além das inscriçốes USA na camisa e NY no boné. Tomando as grifes por signos religiosos, ela lhe pergunta: "Et toi, c'est qui ton dieu?".

7. O liceu francês equivale, mais ou menos, ao atual ensino médio brasileiro.

8. Instituto Universitário de Formação de Professores (maîtres).

9. Em certos textos aparece a designação mais abrangente de Alsácia-Mosela, esta última designando o nome do Departamento que compreende a Lorena.

10. Percebi um certo mal-estar de dirigentes da Federação Protestante da França diante do governo, que trataria os muçulmanos com maior deferência, por causa das ameaças reais ou imaginárias que estes representariam para a política do país, além de serem mais numerosos. Esses dirigentes reclamam, particularmente, da morosidade na autorização na instalação de templos. Um deles chegou a defender a necessidade de revisão da lei de 1905 , sem que isso significasse a mudança de seu apoio ao Estado laico. Aliás, o governo francês rejeitou a instalação da Igreja Universal do Reino de Deus, proveniente do Brasil, mediante a recusa de autorização para a instalação de seu templo.

11. A divisão do Vice-Reinado da Índia, colônia britânica até 1947, deu origem a dois países, definidos grosso modo pelas respectivas maiorias religiosas, que lutavam em sangrentos conflitos: a Índia, de maioria induísta, mas com grande contingente budista, e o Paquistão, de maioria muçulmana. No primeiro, o ensino é totalmente laico nas escolas públicas, en- 
quanto que, no segundo, o Islã foi declarado religião oficial e permeia todo o ensino público. No Paquistão há colégios eleitorais separados por religiôes e a legislação e os preceitos sociais são aprovados pela Corte Federal da Sharia.

\section{Referências bibliográficas}

ASSOCIATION FRANCOPHONE D'ÉDUCATION COMPARÉE. Colloque Education, Religion, Laücité. Disponível em: <http://afecinfo.free.fr/ ERL05/erl-VF_programme_pdf.htm>. Acesso em: 10 nov. 2005.

BLANDIN, A. et al. La religion à l'école en France: débat. Revue Internationale d'Éducation, Sèvres, n. 36, jul. 2004.

CUNHA, L.A.; CAVALIERE, A.M. L'enseignement religieux aux écoles publiques brésiliennes: formation des modeles hégémoniques. In: Baba-Moussa, A.R. (Coord.). Éducation, religion, laïcité: regard croisé et enjeux; pays du Sud et du Nord. Education Comparée, Louvain La Neuve, n. 62, p. 125-148, 2006.

DEBRAY, R. L'enseignement du fait religieux dans l'école lä̈que. Paris: Odile Jacob, 2002.

DOSSIER École et religion. Revue Internationale d'Éducation, Sèvres, n. 36, jul. 2004.

ESTIVALEZES, M. L'enseignement religieux en France: un état des lieux de la situation contemporaine. In: Willaime, J.-P.; Mathieu, S. (Org.). Des maîtres et des dieux: écoles et religions en Europe. Paris: Belin, 2005.

FERRARI, A. Les ambigüités de la "saine laïcité" de l'État italien. In: Willaime, J.-P.; Mathieu, S. (Org.). Des maîtres et des dieux: écoles et religions en Europe. Paris: Belin, 2005.

JACKSON, R. La place de la religion dans l'enseignement en Anglaterre. Revue Internationale d'Éducation, Sèvres, n. 36, jul. 2004.

JACKSON, R. L'évolution vers um enseignement religieux multiconfessionnel en Grande-Bretagne. In: Willaime, J.-P.; Mathieu, S. (Org.). Des maîtres et des dieux: écoles et religions en Europe. Paris: Belin, 2005. 
KOENIG, M. L'État-nation allemande à l'épreuve des mutations de l'enseignement religieux. In: Willaime, J.-P.; Mathieu, S. (Org.). Des maîtres et des dieux: écoles et religions en Europe. Paris: Belin, 2005.

PACE, E. L'insigne faiblesse de la laïcité italienne. In: Willaime, J.-P.; Mathieu, S. (Org.). Des maîtres et des dieux: écoles et religions en Europe. Paris: Belin, 2005.

REMI, B. L'enseignement de la religion en Italie et en France: étude juridique et comparative. Disponível em: <http://afecinfo.free.fr/ ERL05/erl-VF_programme_pdf.htm>. Acesso em: 10 nov. 2005.

SCHREINER, P. La religion à l'école en Allemagne. Revue Internationale d'Éducation, Sèvres, n. 36, jul. 2004.

SCHREINER, P. École et enseignement religieux en République Fédérale d'Allemagne. In: Willaime, J.-P.; Mathieu, S. (Org.). Des maîtres et des dieux: écoles et religions en Europe. Paris: Belin, 2005.

THOMAS, G.M. Les États-Unis, la plus religieuse et la plus sécularisée des nations. In: Willaime, J.-P.; Mathieu, S. (Org.). Des maîtres et des dieux: écoles et religions en Europe. Paris: Belin, 2005.

WILlAIME, J.-P.; MATHIEU, S. (Org.). Des maîtres et des dieux: écoles et religions en Europe. Paris: Belin, 2005. 